\title{
VIOLÊNCIA SIMBÓLICA DA POLARIZAÇÃO: ESTRATÉGIA DISCURSIVA DE DESQUALIFICAÇÃO DO OUTRO NO DISCURSO PÚBLICO-INSTITUCIONAL ${ }^{1}$
}

\author{
SYMBOLIC VIOLENCE OF POLARIZATION: \\ DISCURSIVE STRATEGY OF DISQUALIFYING THE OTHER IN PUBLIC- \\ INSTITUTIONAL SPEECH
}

DOI 10.20873/uft2179-3948.2021v12n1p191-210

\author{
Ana Cláudia Dias Ribeiro ${ }^{2}$ \\ Álvaro José da Silva Fonseca ${ }^{3}$ \\ Janete Silva dos Santos ${ }^{3}$
}

\begin{abstract}
Resumo: Neste artigo analisam-se efeitos de sentido em torno da polarização político/ideológica, mobilizada como estratégia para descontruir o outro junto à opinião pública. Foca-se a polarização construída em fragmentos discursivos que circulam e se (re)produzem no espaço virtual, com objetivo de compreender como se dá a formulação, a constituição e a circulação dessas discursividades na rede. Nesta investigação são analisados recortes discursivos no espaço digital nos quais o "negro" e o "racismo" apontam para a (não) identificação da posição-sujeito em relação a posição social do enunciador. A análise aponta que os sujeitos são deslocados para posições discursivas num movimento de construção pautado na polarização do debate político em que a subversão do discurso público-institucional provoca efeitos de (não)identificação da posição-sujeito, produzindo um sentido "já lá". Ou seja, compreende-se que a posição-sujeito-sócio-histórica aponta para uma (não)identificação com a posição-sujeito social do enunciador.
\end{abstract}

Palavras-chave: sujeito; (não)identificação; sentido; rede.

Abstract: In this article, meaning effects around the political/ideological polarization, mobilized as a strategy to deconstruct the other in public opinion, are analyzed. It focuses on the polarization built on discursive fragments that circulate and (re)produce themselves in the virtual space, with the aim of understanding how the formulation, constitution and circulation of these discursives takes place in the network. In this investigation, discursive clippings in the

\footnotetext{
${ }^{1}$ Artigo formulado a partir das leituras e discussões realizadas no Grupo de Estudos Tocantinenses em Análise de Discurso-GETAD, do qual fazemos parte, no Programa de Pós-Graduação em Letras: Ensino de Língua e Literatura da Universidade Federal do Tocantins - Campus Araguaína.

${ }^{2}$ Doutoranda do Programa de Pós-Graduação em Letras: Ensino de Língua e Literatura (PPGL), da Universidade Federal do Tocantins (UFT), Araguaína (TO). Professora efetiva do Instituto Federal de Ciências e Tecnologia de Rondônia (IFRO), Campus PVH Zona Norte. E-mail: ana.ribeiro@ifro.edu.br

${ }^{3}$ Doutorando do Programa de Pós-graduação em Letras: Ensino de Língua e Literatura (PPGL) pela Universidade Federal do Tocantins (UFT), Araguaína (TO). E-mail: alvaro.fonseca@uft.edu.br

3 Doutora em Linguística Aplicada. Docente do curso de Letras e do PPGL-UFNT/UFT. E-mail: janetesantos@uft.edu.br
} 
digital space are analyzed in which "black" and "racism" point to the (non) identification of the subject-position in relation to the enunciator's social position. The analysis points out that the subjects are moved to discursive positions in a construction movement based on the polarization of the political debate in which the subversion of the public-institutional discourse provokes effects of (non)identification of the subject-position, producing a meaning "already there". In other words, it is understood that the socio-historical-subject-position points to a (non)identification with the enunciator's social-subject-position.

Keywords: subject; (no) identification; sense; network.

\section{Introdução}

O que chamaremos neste estudo de discurso público-institucional encontra na imprensa um espaço de ressonância com grande alcance em termos de construção de um senso comum. Uma das vertentes desse tipo de discurso (o político) situa-se na esteira dos sentidos em torno da política nacional e na (re)produção dos discursos que circulam na rede pelas discursividades jornalísticas. Como recorte dessa manifestação discursiva, lançamos um olhar sobre os efeitos políticos produzidos em dizeres de jornais (em suas diversas manifestações, impressos ou digitais) que assumem e inscrevem a noção dividida de polarização político-ideológica a partir da oposição entre sujeitos de esquerda e de direita, distinção tomada como um sentido "já lá". Tal "evidência" põe em funcionamento relações de conflito, dissenso e violência.

Implicados em não tomar esses efeitos como uma "evidência" buscamos a analisar como o discurso da polarização cria espaço para um dizer regulado pela violência entre os sujeitos de esquerda e de direita.

Problematizamos essa noção a partir dos fundamentos teórico-metodológicos da Análise de Discurso (AD), preconizada por M. Pêcheux e E. Orlandi, a qual toma sentidos e sujeitos como constituídos segundo sua realização em diferentes formações discursivas, nos mais variados campos (político, ideológico, moral, econômico, cultural, religioso, científico etc.) e situados segundo determinações sociais e históricas. Desse modo, a institucionalidade, em suas discursividades, afetam os sujeitos, direcionando sentidos.

Nessa perspectiva, levamos em conta que os sentidos construídos pela linguagem não estão dados, mas são construídos a partir de um ritual que a torna opaca, dispersa, sujeita às falhas constitutivas no processo de significação. Desse modo, consideramos que o objeto discursivo em análise se caracteriza pela turbidez de sua manifestação, sendo reconhecido por diferentes grupos como um dito óbvio, visto, por isso mesmo, inadmissível seu emprego no 
campo da contradição. Ou seja, trata-se do discurso público-institucional, vinculado aos sentidos do senso comum, daquilo que já é sabido, que não encontra espaço para se questionar.

Assim, nosso objetivo neste estudo é problematizar os efeitos de sentido produzidos pela noção de "polarização" político-ideológica construída em fragmentos discursivos que circulam e se (re)produzem no espaço virtual. São textualidades elaboradas por sujeitos, posicionados discursivamente em "polos opostos", que, constituídos a partir da divergência, mobilizam efeitos contraditórios permitidos pela historicidade, pelo interdiscurso e pela memória.

Destarte, buscamos compreender os processos que autorizam a inscrição dos sujeitos a determinados movimentos contraditórios no espaço da internet. Para tanto, nosso corpus é construído por 04 (quatro) recortes discursivos da web em que circunscrevemos a manifestação material de um sujeito determinado pela contradição político-ideológica; e notamos a manifestação da violência materializada em diferentes gestos de leitura produzidos num perfil do Facebook.

É central nesses recortes o atravessamento pelo discurso sobre o negro, materializada na tomada de posição dos sujeitos. Ou seja, as discursividades são mobilizadas por um sujeito cuja posição social reclama, em função da historicidade constitutiva dos sentidos, determinada posição discursiva que não é assumida nas textualidades. Temos aí a chave para expor o funcionamento da violência a partir da contradição das posições político-ideológicas.

Cabe esclarecer que não estamos lidando com o empírico, com o real da história. Pontuamos isso para deixar o mais evidente possível que os efeitos dessa contradição nos afetam, enquanto sujeitos pesquisadores, de maneira bastante distinta daquela que é mobilizada pelos enunciados do sujeito político que estamos discutindo, especialmente tendo em vista que nossa motivação ao realizar esta análise revela nossa posição enquanto sujeitos. Salienta-se que a ética do analista de discurso não está na sua neutralidade (impossível, registre-se de antemão), mas no rigor teórico-metodológico com que conduz sua análise.

\section{Constituição dos sujeitos}

Para a perspectiva da Análise de Discurso (AD), o indivíduo se torna sujeito do discurso na/pela linguagem ao ser interpelado pela ideologia, o que torna possível toda forma de significação, ou seja, a relação entre língua e ideologia produz discurso, efeitos de sentido. Nesse processo, os sentidos se constituem, de uma forma ou de outra, por meio da 
operacionalização do interdiscurso (ideológico) pela formação discursiva, na qual os sujeitos se inscrevem.

Segundo Pêcheux (2014), formação discursiva é “aquilo que, numa formação ideológica dada, isto é, a partir de uma posição dada numa conjuntura dada, determinada pela luta de classes, determina o que pode e deve ser dito (PÊCHEUX, 2014a, p. 147, itálicos do autor). Isso ocorre de forma inconsciente, levando o sujeito à "ilusão" de que é ele a origem do "dizer" e de que o que ele diz só pode ser dito daquela maneira. Indursky (2008) esclarece que a noção de formação discursiva está para uma relação entre a ideologia vigente e um domínio de saber constituído de enunciados discursivos. Tratamos aqui, pois, de sujeitos discursivos interpelados ideologicamente que operam na linguagem por meio de formações discursivas constituídas sócio-historicamente.

Vale ressaltar que a formação discursiva tem por caraterística a heterogeneidade, por conta do sujeito dividido concebido pela AD. No âmbito de determinada formação discursiva, é possível haver disputas de sentidos entre os saberes a esta circunscritos, produzidos por outras formas-sujeito, assumidos por outras posições-sujeito, ou até mesmo contrapostos a outras FD. Desse modo, para além da igualdade, abre-se espaço para diferença e divergência, estabelecendo, assim, a contradição de sentidos. (INDURSKY, 2008).

Para Pêcheux (2014 [1975]), “a interpelação do indivíduo em sujeito de seu discurso se realiza pela identificação do sujeito com a formação discursiva que o domina, identificação na qual o sentido é produzido como evidência pelo sujeito" (p. 238). Em outras palavras, ao assumir uma determinada posição ideológica, o sujeito o faz mobilizando os mecanismos da língua sob os pré-construídos de uma dada formação discursiva. Consideremos, por exemplo, que a discursividade jurídica se inscreve numa formação discursiva do direito que se torna possível pela materialização discursiva da instituição jurídica, sendo a própria instituição efeito provocado pela historicidade das condições materiais de produção. Nisso, ocorre um processo de individuação do sujeito, por meio das instituições, visto que o homem é um sujeito sóciohistórico. No entanto, sabemos que o Estado falha na individuação do sujeito, assim como há falha no ritual ideológico, além disso, o sujeito é também afetado pelo inconsciente que o constitui.

É importante ressaltar que para a $\mathrm{AD}$ os sentidos não estão presos à língua, e sim em movimento, sempre "em relação à”, e o significado das formulações linguísticas tem a ver com 
as formações discursivas/ideológicas nas quais esses enunciados são inscritos. Pêcheux (2014a, p.146-147), sistematizando esse movimento, explica que:

[...] as palavras, expressões, proposições, etc. mudam de sentido segundo as posições sustentadas por aqueles que as empregam, o que quer dizer que elas adquirem seu sentido em referência a essas posições, isto é, em referência às formações ideológicas nas quais essas posições se inscrevem.

Esse é um aspecto fundamental para se compreender o papel do histórico no discurso. Esses sentidos postos em movimento funcionam estabelecendo uma memória, constituída pelo esquecimento da origem do dito. Ou seja, os dizeres se tornam parte do interdiscurso e passam a produzir efeitos distintos quando inscritos em determinadas formações discursivas. Desse modo, a memória discursiva opera as interdiscursividades e cria os sentidos possíveis no processo de significação.

Tratamos aqui, pois, de sujeitos discursivos interpelados ideologicamente que operam na linguagem por meio de formações discursivas constituídas sócio-historicamente. É por meio da interpelação-assujeitamento que o sujeito se constitui e se inscreve em uma dada formação discursiva, pois, conforme Pêcheux:

É a ideologia que fornece as evidências pelas quais "todo mundo sabe" o que é um
soldado, um operário, um patrão, uma fábrica, uma greve tec. Evidências que fazem
com que uma palavra ou enunciado "queiram dizer o que realmente dizem" e que
mascaram, assim, sob a "transparência da linguagem" aquilo que chamaremos o
caráter material do sentido das palavras e dos enunciados. (Pêcheux 2014 [1975],
p.146)

Esse funcionamento ideológico é que coloca para o sujeito o já-dito, um sentido que lhe parece evidente e natural. Nesse ponto, cabe situarmos o sujeito de nossa análise no campo da contradição, daquilo que escapa à regularidade e provoca a dispersão, o equívoco, a falha do que, como efeito, está tomado como uma obviedade. Esse é o lugar da política, da cisão dos sentidos, onde se estabelece o confronto, onde a violência encontra espaço.

É nesse lugar que o sujeito cria sentido a partir da forma-sujeito estabilizada institucionalmente. No entanto, Pêcheux (2014 [1975]) explica que o processo de interpelação ideológica está sujeito a falha ou enfraquecimento, ou seja, não é definitivo, imutável visto que o sujeito não ocupa apenas uma posição social. Assim, esse funcionamento abre possibilidade para os processos de ruptura e transformação que por sua vez, também, são constituídos ideologicamente: "O lapso e o ato falho (falhas do ritual, bloqueio de ordem ideológica) bem 
que poderiam ter alguma coisa de muito preciso a ver com esse ponto sempre-já ai, essa origem não detectável da resistência e da revolta [...]" (PÊCHEUX 2014 [1975], p.278).

A forma-sujeito histórica é produto das relações de produção no capitalismo, em que a forma-sujeito de direito produz efeitos sobre a noção de indivíduo responsável. De acordo com Orlandi (2017) “O Estado capitalista, regendo-se pelo jurídico, individualiza o sujeito, responsabilizando-o, fazendo funcionar a relação entre direito e deveres” (p. 156). Entra em cena, portanto, o jogo entre liberdade e submissão do sujeito. O sujeito tem a ilusão de que é "dono", origem de seu dizer e responsável pelas suas escolhas, quando, na verdade, ele é determinado sócio-historicamente, sendo ao mesmo tempo um sujeito ético e político.

O sujeito político na presente leitura constrói-se a partir de algumas injunções do simbólico. Trata-se de um sujeito polarizado, efeito dos acontecimentos históricos da contemporaneidade em que se materializam concepções ideológicas imbuídas no "resgate" do passado enquanto lugar de preservação das boas práticas morais. Também, esse sujeito se caracteriza pela ressignificação da memória a fim de criar novos sentidos e estabelecer novas formas de legitimação para determinados movimentos autoritários. Ao mesmo tempo, esse sujeito afirma sua posição contraditória, inscrevendo-se no lugar imaginário de que as determinações histórias ignoram as contradições étnico-raciais e primam pelo indivíduo enquanto ser de direito, pleno de liberdade. Tal gesto é, portanto, da ordem do imaginário.

Pensando-se na forma-sujeito histórica afetada pela relação autorização/interdição, temos que os enunciados dos sujeitos de nossa análise mobilizam sentidos inscritos no que está autorizado ou não em determinadas formações discursivas, tanto aqueles vinculados à polarização política, esquerda x direita, quanto os vinculados à memória histórica. Sobre esta última, realizamos um recorte sobre os sentidos do que se estabilizou como racismo, especialmente acerca dos efeitos históricos da escravidão dos sujeitos negros. Temos, então, a caracterização de um sujeito político, produto da contradição constitutiva dos sentidos sobre a polarização tomada como evidente entre "esquerda" e "direita", e sobre os efeitos não evidentes do "racismo". Assim, considerando o aspecto determinante sobre o ponto de nossa análise, buscamos expor o modo como funciona essa contradição, reiteramos, sob os dispositivos teóricos da $\mathrm{AD}$.

Parece-nos que o processo discursivo aponta para uma tensão, na qual os sentidos são divididos e dependem das condições de sua produção. De modo que "esquerda" pode significar coisas diferentes para quem se inscreve como apoiador de um governo de direita e para quem 
lhe faz oposição. A simetria é possível em relação à noção de "racismo", que pode fazer circular diferentes efeitos de sentido a depender de quem diz, de onde diz e para quem. Entra, nessa questão, a memória discursiva responsável pela autorização de certos sentidos e o apagamento de outros.

\section{Racismo: lugar de disputa}

Para a AD, todo dizer se constitui a partir de um já-dito, isto é, de uma memória. Ao enunciar, ocorre a tomada de posição do sujeito em relação a uma memória, entre outras. Para as palavras significarem é preciso que (re)produzam uma memória discursiva. De acordo com Orlandi (2017) "a essa memória constitutiva e discursiva, chamamos interdiscurso. Face a ela, os sentidos se estabilizam, nela os sentidos se movimentam" (p. 171, itálico da autora). Essas movimentações vão depender do gesto de interpretação e da posição do sujeito e sua filiação, de modo que o interdiscurso está na ordem do que é possível de ser dito e, enquanto a formação discursiva, diz respeito ao que "pode e deve ser dito" (PÊCHEUX, 2014a, p. 147) pelo sujeito.

Responsável pela estabilização dos sentidos pela memória institucionalizada, temos o que chamamos de arquivo, por meio do qual se realiza o efeito de completude, compreendendo o dizer realizado. Pelas palavras de Pêcheux (2014, p. 59) o arquivo compreende o "campo de documentos pertinentes e disponíveis sobre uma questão".

No Brasil, existe uma memória construída em um dado momento histórico que buscou homogeneizar o padrão identitário, evidenciando ranços da democracia racial e da assimilação à brancura. Assim, a cor da pele passou a ser constituidora de identidade, assumindo uma marca pejorativa para uns, valorativa para outros.

Podemos considerar que a relação de distintividade entre grupos sociais, especialmente no tocante a fatores étnico-raciais, ganhou inscrição na história brasileira de modo a produzir efeitos de desigualdade social. Opera aí um imaginário que posiciona esses grupos em diferentes espaços de legitimidade no conjunto da sociedade, sobretudo criando uma relação contraditória entre eles. Assim, a "descendência europeia”, dita branca, funciona no imaginário social como um fator de superioridade cultural, moral e religiosa em relação aos não europeus, sobretudo, africanos. Cria-se aí, de um modo geral, os fundamentos sociais para os sentidos do racismo localizado na relação negro-branco. 
Diante dessa premissa, é possível assumir que, no Brasil, existe em funcionamento uma memória discursiva que direciona os sentidos para a hegemonia dos brancos sobre os negros, sobretudo no que tange a estrutura sobre a qual os fundamentos do estado capitalista estão montados, em que a diferença é uma questão presente no exercício das práticas sociais. Para Orlandi (2017, p.17) o racismo é uma forma de censura que opera sobre o corpo, sobre a cor. Diz respeito ao modo como o Estado individua os sujeitos, produzindo estigma e divisão política.

Ademais, vivenciamos, no Brasil, uma polarização instalada nas relações sociais brasileiras que se encontra assentada na divisão constitutiva das noções político-ideológicas de "esquerda" e "direita", postas em ampla circulação pelas mídias digitais. Nosso enfoque está no momento histórico representado pela eleição presidencial de 2018 no Brasil, especialmente porque mobiliza memórias já estabilizadas no imaginário e que ganharam abertura para uma maior circulação, de acordo com Mariani (2019).

Nesse contexto, podemos apontar discursividades condensadas no que é possível representar como formações discursivas antagônicas: uma que toma o racismo como estrutural, para a qual políticas públicas (lei de cotas, por exemplo) como um projeto de reparação histórica da barbárie humana sofrida pela população negra do país; e outra que toma o racismo como circunstancial, a qual inscreve-se nos sentidos da individualidade meritocrática, ou seja, políticas públicas baseadas em cor da pele promovem discursos vitimistas sobre a população negra. A violência se manifesta quando a heterogeneidade dessas formações discursivas produz contradição no interior dos discursos, ou seja, quando se inscreve numa e se tenta deslegitimar a outra. Nesse sentido, vale trazer aqui considerações de Possenti e Oliveira (2021, p. 9) sobre a violência:

O conceito de violência varia bastante conforme o campo que o mobiliza, a ponto de alguns sociólogos e psicólogos preferirem empregar o termo sempre no plural (MARIN, 2002). Parece haver relativo consenso, entretanto, de que a violência não se resume a agressões físicas, mas abrange a violência psicológica e verbal, para citar as principais concepções, bem como forma menos visível de violência, a simbólica.

No nosso caso, interessa-nos compreender a violência simbólica _ que, ressaltam Possenti e Oliveira, "é certamente a forma menos percebida" (ibid.) _ no funcionamento discursivo contraditório em torno do racismo. É fundamental que, para isso, retomemos 
algumas condições históricas sobre o racismo no Brasil, foco de disputa dos sentidos nos enunciados analisados. Tratamos aqui o racismo como fato social que tem a memória como elemento central, uma vez que, para a $\mathrm{AD}$, não se separa o dentro e o fora, sendo, assim, a memória exterioridade constitutiva.

\section{Discursos nas redes}

A posição-sujeito é o movimento de identificação do enunciador, afetado pela formasujeito do discurso. Refere-se à tomada de posição em relação ao saber discursivo (científico, jornalístico, senso comum etc.). É importante ressaltar que as posições do sujeito são intercambiáveis, mas uma posição-sujeito "x" e uma posição-sujeito "y" não se equivalem, uma vez que os sentidos produzidos não são iguais. Isso porque o sujeito, adverte Grigoletto (2005, p.7):

\footnotetext{
ao se inscrever em um determinado lugar discursivo, vai se relacionar tanto com a forma-sujeito histórica e os saberes que ela abriga quanto com a posição-sujeito. Assim, a relação do sujeito enunciador com o sujeito do saber e, consequentemente, com a posição-sujeito é deslocada para as relações de identificação/determinação do lugar discursivo tanto com a forma-sujeito histórica (ordem da constituição/do interdiscurso), quanto com a posição-sujeito (ordem da formulação/do intradiscurso)
}

Assim, caracteriza-se como lugar social aquele que diz respeito à formação sóciohistórica do sujeito empírico. Enquanto o lugar discursivo está relacionado à identificação do sujeito do discurso com a forma-sujeito que se conecta com o lugar social, o qual é determinante do/no seu dizer (materialidade da língua). No entanto, essa sobredeterminação pode ser rompida pela incidência do real, fazendo com que o sujeito se filie a outra rede de saberes. Esse desencaixe pode ser observado por meio do funcionamento do processo de identificação dos sujeitos a determinadas formações discursivas, bem como à negação de outras.

No processo de movimentação de sentidos, a identificação do sujeito ocorre de forma fragmentada em relação à formação discursiva, de modo que o sujeito do discurso pode não se identificar com a totalidade dos saberes da formação discursiva a qual ele se inscreve, mas apenas com parte dos saberes que nela circulam. De acordo com Indursky (2008), a desidentificação do sujeito pode ocorrer de duas formas, a saber: na primeira, o sujeito do discurso se desidendifica de uma forma-sujeito, assumindo outra forma-sujeito; a segunda 
ocorre quando o sujeito do discurso desidentifica-se com um domínio de saber ao qual identificava-se e se filia a um novo domínio de saber, que está ainda se constituindo.

Dias (2018, p.156) chama de sujeito de dados aquele que faz sua postagem nas redes sociais, fazendo da internet "um espaço de escritura de si, não é à toa que a mais preciosa 'moeda' da rede sejam os dados dos sujeitos: o que come, onde ele vai, onde mora, onde trabalha, qual sua posição política, seu poder aquisitivo”. Esse modo de dizer de si funciona como dados organizados algoritmicamente e mobilizados politicamente nas redes sociais. Desse modo, as discursividades movimentadas nas redes sociais circulam para serem significadas (são vistas, são lidas, são curtidas, são questionadas, são compartilhadas etc.). Esses processos direcionam os sentidos de modo a legitimar determinados dizeres de acordo com o modo como se dá sua circulação nas redes. A instrumentalização desses algoritmos pode desencadear efeitos de evidência, o que afeta a identificação de determinados grupos a determinadas lutas e formas de mobilização política, em especial, formas violentas de se posicionar nas redes.

\section{O sujeito contraditório: a violência que funciona no discurso}

As eleições de 2018 representam um marco para nosso estudo, pois evidenciou a radicalização da noção de polarização política no cenário político-ideológico brasileiro. Nesse contexto, as redes sociais irromperam como uma força comunicativa de massas e ganharam destaque como espaço para a contradição dos sentidos postos como evidência.

Dentre os dissensos, apontamos a questão do racismo, até então tomada como pacificado no debate público, efeito do discurso hegemônico. A contradição se marca ao circular nas redes os dizeres de um sujeito que, considerando a FD dominante acerca do racismo, pode ser inscrito numa posição alvo de ataques: a posição social de negro. Contudo, opera em seu dizer uma denegação, uma ruptura do imaginário.

O caso material a que nos referimos trata do enunciado produzido em setembro de 2019 numa rede social por um sujeito nomeado como "Sérgio Camargo", sobre o qual é possível mobilizar dizeres hegemônicos acerca dos sentidos do racismo. Segue o recorte:

\section{Recorte discursivo 1}




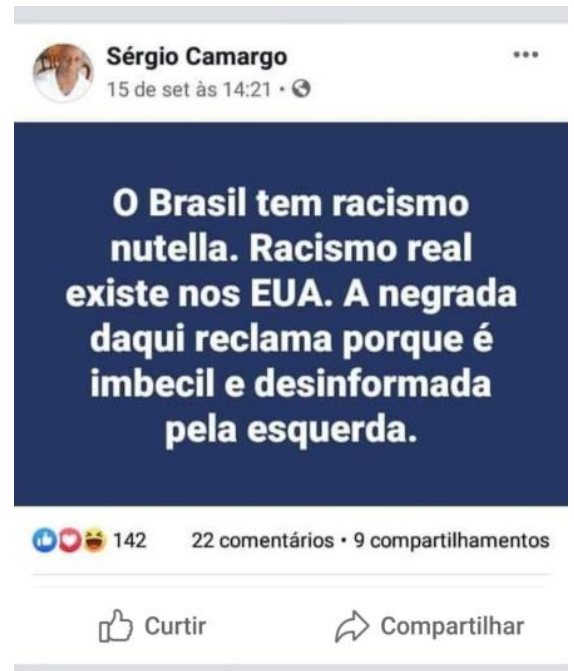

Fonte: Facebook

O enunciado faz operar a memória metálica (cf. ORLANDI, 2010) a partir das relações que estabelece com o meme $e^{4}$ de estrutura polêmica “raiz x nutella”. Essa estrutura, por sua vez, inscreve-se numa rede de sentidos constituída pela contradição. Logo, diversas elaborações passaram a circular na internet relacionando "raiz" e "nutella" para designar aquilo que, no primeiro, está no campo da originalidade, do explícito, da profundidade, autêntico; no segundo, deriva como uma imitação de efeitos "gourmetizados", daquilo que emerge como maquiado, superficial, sem conteúdo, trabalhado sobretudo visando a um efeito estético (cf. OLIVEIRA, 2016, 2018). Desse modo, o texto produz efeitos polêmicos, vinculados à contradição ao retomar a memória da estrutura memética formulada segundo uma relação de deslocamento do referencial:

\begin{tabular}{|c|c|}
\hline$x$ raiz & $x$ nutella \\
\hline$y$ & $z$ \\
\hline
\end{tabular}

Que poderíamos substituir com os elementos enunciativos da postagem:

\begin{tabular}{|l|l|}
\hline Racismo "real" & Racismo nutella \\
\hline
\end{tabular}

\footnotetext{
${ }^{4}$ Gêneros discursivos (verbais, imagéticos ou multissemióticos) de tom humorístico (mesmo produzindo humor sádico pela violência simbólica que alguns desses gêneros operam) que circulam pela web.

${ }^{5}$ Efeitos próprios do mercado de consumo constitutivo da lógica capitalista (cf. PALMERI JÚNIOR, 2017). Os sentidos da gourmetização operam, metaforicamente, pela diferenciação, contrapondo referenciais semelhantes, mas destacando diferenças construídas para valorizar mais um em detrimento do outro. É a própria ideia reproduzida na palavra nutella empregada no enunciado, que retoma sentidos do campo discursivo gastronômico para diversos outros espaços de circulação do discurso.
} 


\section{\begin{tabular}{l|l} 
EUA & BRASIL \\
\hline
\end{tabular}}

E ainda derivações:

\begin{tabular}{|c|c|}
\hline Negrada "real" & Negrada "nutella" \\
\hline $\begin{array}{c}\text { (não) reclama } \\
\text { (não) imbecil } \\
\text { (não) desinformada pela esquerda }\end{array}$ & $\begin{array}{c}\text { Reclama } \\
\text { Imbecil } \\
\text { Desinformada pela esquerda }\end{array}$ \\
\hline
\end{tabular}

Assim, estabelece-se uma relação entre um referente comum (racismo) situado em dois espaços de memória distintos que são posicionados no discurso segundo o julgamento polêmico. Ou seja, os sentidos do original, do barra pesada, do autêntico está inscrito nos sentidos dos "EUA", enquanto o BRASIL seria a imitação, a adaptação "gourmetizada".

O texto em questão se manifesta como uma postagem caracterizada pelo gesto de produção nas redes constitutivo do espaço de circulação do enunciado, ou seja, conforme Dias (2019, p. 64), "No Twitter, o sujeito tuíta, no Facebook, no blog, ele posta". Desse modo, conforme Dias (2019), o fato de a postagem que pomos em evidência nesta análise circular no Facebook já produz efeitos próprios desse espaço discursivo:

[...] o postar resulta de uma relação de significação entre a escrita e o meio, uma vez que postar inclui o percurso, o compartilhamento, a visualização, a "curtida". Essa relação de significação entre a escrita e o meio que caracteriza o modo de textualização do postar se inscreve no processo da circulação, um dos três momentos do processo de construção dos discursos, a saber, o da circulação, o da constituição e o da formulação, conforme postulou Orlandi (2001). Uma postagem tem que circular. A circulação é parte da constituição do sentido do postar. É pela circulação que se dá sua eficácia tecnológica, sendo a viralização o grau máximo dessa eficácia. $\mathrm{O}$ viral é a atestação da circulação, mas não é garantia de historicização do sentido, não é garantia da verticalização da memória. Pela característica do viral que é a replicação, o excesso do dito é justamente esse retorno do mesmo que o impede de significar na história, fazendo-o expandir-se horizontalmente. (DIAS, 2019, p. 64)

O layout da postagem também funciona como um destaque, uma linguagem memética, que põe em evidência os efeitos da chacota, do humor que pretende disfarçar a carga pesada da contradição, dos efeitos da não-identificação. Esse gesto está descrito por Indursky (1990) quando a autora aponta a denegação como constitutiva da relação entre a contradição no interior de uma dada formação discursiva. Nesse sentido, a negação se instaura uma vez que a identificação com a formação discursiva - que se dá quando o sujeito se posiciona diante da problemática do racismo, reivindicando uma posição de sujeito legítima para enunciar acerca 
de tal tema - é subvertida pela negação afirmativa (sem que o enunciado seja negativo o enunciador subverte a formação discursiva segundo a qual o Brasil possui racismo tal qual os EUA). Aliás, o racismo pode se dar em outros lugares, tanto países quanto estados brasileiros. Sendo uma categoria jurídica, o racismo pode se dar não somente em relação ao tom de pele ou características físicas que definem grupos étnicos, mas também em relação a pessoas de outras regiões, pela identificação de gênero (homofobia), pela crença religiosa. O enunciado em questão retoma o racismo étnico e compara duas noções totalizantes de países distintos (BRASIL e EUA) relacionando os sentidos em torno dessas noções. Ao direcionar os sentidos do racismo, deixa aberta outras noções de ordem histórica, econômica, social, política etc.

Na postagem, lemos a afirmação de que o racismo existente no Brasil é do tipo "nutella". Podemos observar nesse enunciado a mobilização do nome próprio "Nutella" - famosa marca de creme de avelã que, por ser um produto caro, tornou-se mais popular entre as classes abastadas. Um dos significados para esse nome é dado pelo site do Dicionário Informal ${ }^{6}$ online, que o define como "fresco, mimado". Considerando os efeitos dessa palavra enquanto uma marca de doce/sobremesa vinculada a um consumo regular da classe média ou alta, e sua dispersão para o campo da fragilidade física e emocional desses grupos em oposição à brutalidade e da resiliência das classes baixas, assumimos a estabilização de determinada formação discursiva na qual o sujeito se inscreve, uma vez que, na sequência, esse nome funciona como qualificador do substantivo "racismo". Assim, por meio de um processo metafórico de deslizamento de sentidos, "nutella" mobiliza a memória outra e desloca o imaginário sobre o negro, colocando esse sujeito numa posição de privilégio social. O racismo no Brasil seria frescura.

Na sequência, a palavra "real" adjetivando o nome "racismo", colocando-o em oposição a "nutella", podemos esboçar como uma possibilidade de gesto interpretativo em que se estabelece uma relação de determinação da classe social sobre o sujeito. O negro que se coloca, portanto, como vítima de racismo, seria fraco.

Ao continuar o enunciado - "a negrada daqui reclama porque é imbecil e desinformada pela esquerda" - o sujeito inscreve o texto na formação discursiva da política, mobilizando os sentidos em torno da disputa. Existe aqui mais um componente de identificação do sujeito à formação discursiva que denega. Ao encaixar o elemento "negrada", o sujeito produz inscrição

\footnotetext{
${ }^{6}$ Disponível em: https://www.dicionarioinformal.com.br/sinonimos/nutella/ (acesso em 26/04/2020).
} 
no campo da legitimidade (falo com os iguais a mim). Esse dito poderia ter sentidos diferentes se fosse produzido por um sujeito "branco".

Em oposição, o sujeito não se inscreve como negrada, nem, consequentemente, como manipulado, imbecil, nem desinformado pela esquerda. Isso num movimento de afirmação que põe todos os negros como um grupo vinculado à "esquerda". Contudo, o sujeito em questão toma posição como negro, vê-se legitimado a confrontar sua posição e a de outros negros, num gesto de aproximação da posição do outro e de identificação aos brancos como quem diz "me aceitem, eu sou negro, mas não me importo em me submeter a sua lógica de mundo e nem reclamo do racismo que sofro porque poderia ser pior”. Essa leitura se justifica pela inscrição no recorte seguinte, no qual o sujeito "Sérgio Camargo" inscreve seu perfil no Facebook, em dezembro de 2012, como "Negro de direita, contrário ao vitimismo e ao politicamente correto. Negros são livres!":

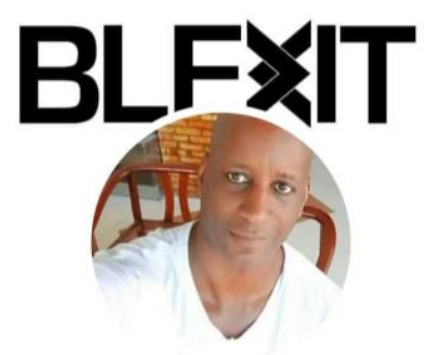

\section{Sérgio Camargo}

Negro de direita, contrário ao vitimismo e ao politicamente correto. Negros são livres!

Se a "negrada" não fosse "imbecil" e "desinformada pela esquerda" - fosse, ao contrário, inteligente e informada pela direita - não reclamaria, já que o racismo que acontece no Brasil não é "real" (raiz), seria uma forma gourmetizada do racismo dos EUA, assim como muitas coisas que importamos de lá, retomando o sentido, também, da colonização desse país sobre nós. Uma outra observação possível é a de que a forma "é imbecil" funciona como predicativo do sujeito "negrada daqui”" (oposição à negrada de lá, que não é imbecil e por isso não reclama). Ou seja, os negros brasileiros são imbecis. A despeito disso ser um lapso e o enunciador ao invés de elaborar a forma predicativa tivesse elaborado "a negrada daqui reclama 
porque é imbecilizada e desinformada pela esquerda", teríamos um processo discursivo diferente que colocaria a esquerda como operador dos sentidos, unido a oração coordenada em uma só, ao invés de duas: "a negrada daqui reclama porque é imbecil"/ "a negrada daqui reclama porque é desinformada pela esquerda". Projeta-se aí dois modos de funcionamento. No primeiro há uma forma ativa. No segundo, uma forma passiva.

A esquerda seria o vetor de desinformação que estaria prejudicando os "negros imbecis" ao desinformá-los. Para o sujeito enunciador, os "negros imbecis" daqui deveriam se informar pela direita. Aí já seria meio caminho andado, vez que ainda se precisaria deixar de ser imbecil.

Tanto as noções de "negrada" e de "esquerda" apontam para uma identificação com o "BRASIL" enquanto a polêmica se instaura nesse segundo enunciado, apontando para os sentidos da direita que informa, e cujos adeptos são sagazes, inteligentes, sentidos que se vinculam ao "EUA", que emerge na postagem como referência dos sentidos "raiz" (direita, inteligente, informada, racismo de verdade). Em oposição, "BRASIL" se vincula aos sentidos "nutella" (esquerda, imbecil, desinformada, racismo leve). Logo, a luta, assumida enunciativamente, contra o racismo por grupos negros no Brasil só acontece porque existe uma manipulação política da "esquerda".

Essa mesma postagem foi reproduzida pela mídia jornalística digital (Recorte discursivo 3), dando-se ênfase (como um gesto de interpretação) ao tema do racismo. Esse destaque temático conduz a leitura tendo como referência a nomeação de Sérgio Camargo, autor das postagens, para o cargo de presidente da Fundação Cultural Palmares, cuja importância simbólica estabelece uma íntima relação com a memória da resistência dos povos escravizados no Brasil, especialmente no tocante à manutenção dos significados culturais mantidos por esses povos e seus descendentes.

Recorte discurso 3

\section{Novo presidente da Fundação Palmares minimiza racismo no Brasil em post; entidades criticam}

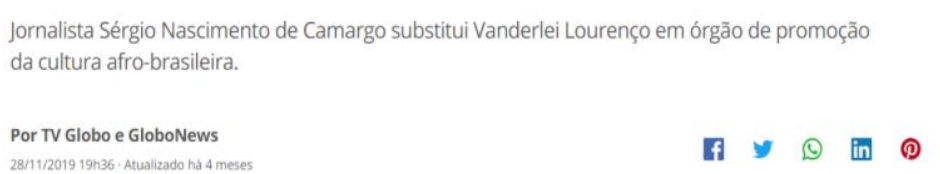

Fonte: g1.com 
Nos recortes discursivos 2 (perfil no Facebook em 15/12/2019) e 4 (perfil no Facebook em 20/04/2020) podemos observar a narratividade que o sujeito faz de si mesmo, vista como uma memória discursiva na qual o sujeito se inscreve no mundo, pelo viés político. Nessa narrativa, o enunciador se identifica como um sujeito negro e de direita, evidenciando um descolamento do lugar discursivo de quem busca igualdade social, de direitos e oportunidades.

Recorte discursivo 2

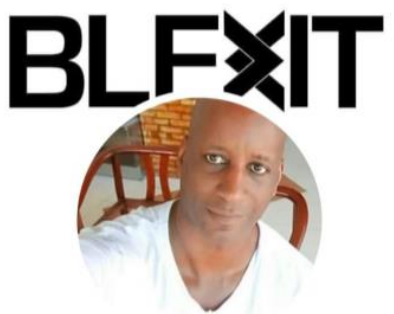

Sérgio Camargo

Negro de direita, contrário ao vitimismo e ao politicamente correto. Negros são livres!
Recorte discursivo 4

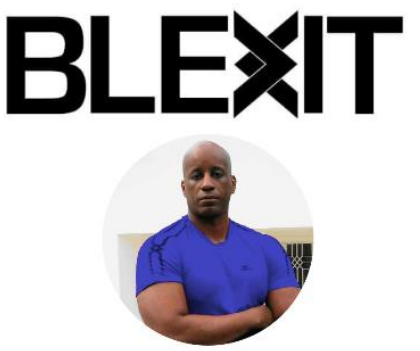

Sérgio Camargo

Presidente da Fundação Cultural Palmares. Negro de direita, antivitimista.

A contradição evidenciada nesses recortes se marca pela identificação do Sergio Camargo como negro. Dessa forma, o enunciado chama a atenção pelo descolamento da formasujeito do lugar social para o lugar discursivo. Ou seja, mobiliza-se um pré-construído de que o sujeito negro dever ser antirracista. Contudo, há um movimento de ressignificação histórica na qual o racismo responderia a outros gestos de interpretação. Ao recortar os dizeres da ciência, o enunciado se inscreve num discurso-outro.

Acima da foto de perfil aparece a palavra BLEXIT ${ }^{7}$ - movimento norte-americano liderado por Candace Owens, ativista que visa a "libertar" os eleitores negros das décadas de domínio do Partido Democrata (partido de esquerda, dos EUA).

A expressão "BLEXIT" retoma a memória do "BREXIT", que ganhou circulação na mídia como um movimento contrário ao "BREXIN". Esse movimento esteve vinculado ao plebiscito realizado em 2016 no Reino Unido a respeito da saída britânica do bloco da União Europeia. Os termos são abreviações construídas pela junção das expressões British exit

\footnotetext{
${ }^{7}$ Disponível em: https://www.foxnews.com/politics/what-is-blexit-candace-owens-explains-plan-to-lead-blackexit-from-democratic-party-impact-2020 (Acesso em 25/04/2020)
} 
(BREXIT) e British in (BREXIN). Esse acontecimento esteve intimamente vinculado à progressão de movimentos classificados nos discursos midiáticos como sendo direita conservadora. Nos EUA, esses sentidos são reforçados com a eleição de Donald Trump, no final de 2016.

Ao se filiar ao dizer "BLEXIT", o sujeito produz uma retomada da memória discursiva que vincula os movimentos conservadores de direita às discursividades produzidas no Brasil. Trata-se de um movimento também de colonização, uma vez que há uma busca pelos sentidos globais, fundados nos EUA por um movimento negro que se identifica como antiesquerda.

Nos recortes discursivos 2 e 4, o sujeito retoma esses sentidos assumindo-se como militante essencialmente antiesquerda, ressiginificado como um movimento de libertação dos negros (BLEXIT = black exit). O político ganha inscrição no social como um movimento de negação do racismo.

O que se observa é um discurso que remonta a memória discursiva de que ser de direita é naturalizado como algo normal, ao contrário de ser de esquerda, que é posto como algo mau, discursividade que vem sendo (re)reproduzida pela mídia desde a fundação do Partido Comunista do Brasil, e utilizada para os demais partidos de esquerda. Temos então um entrecruzamento da discursividade jornalística, posição social ocupada pelo enunciador com a História/história, provocando a ruptura, um desencaixe do lugar discursivo de presidente da Fundação Cultural Palmares. Nesse caso, o não-dito é que o sujeito ser negro e ser de esquerda é uma coisa errada, ou melhor, não é nada bom, marcando uma disputa de forças.

O sujeito constituído pela metáfora encontra-se dividido e o exterioriza, externando o estranho, que ele odeia, o que o separa, e tudo isso vai produzir um efeito na posição-sujeito e na sua formação social, produzindo assim deriva, equívoco, efeitos de historicidade e individuação que definem sua relação com o outro. (ORLANDI, 2017)

O "termo politicamente correto", de acordo com a pesquisadora Moira Weigel ${ }^{8}$, que estava escrevendo um livro sobre a história do politicamente correto, repercutiu nos EUA após um momento de intenso conflito. Antes disso, era utilizado pela esquerda de forma irônica para chatear quem agia radicalmente como moralista. Por volta dos anos 90 passou a ser utilizada pela direita para criticar professores universitários acusados de ensinar ideias radicais e de esquerda, que estavam influenciando negativamente os acadêmicos. Possibilitando-nos

\footnotetext{
${ }^{8}$ Disponível em: https://epoca.globo.com/estudiosa-do-politicamente-correto-afirma-que-ele-nao-existe-uminimigo-imaginario-23374222 (Acesso em 20/01/2021)
} 
perceber os atravessamentos de sentidos de um mesmo termo entre diferentes FDs (esquerda/direita).

Observando outras postagens que se seguem as que selecionamos para esta análise, vislumbramos um deslizamento metafórico na palavra escravidão, que numa FD da direita significar aprisionamento mental e ideológico, modificando assim a perspectiva da luta contra escravidão, que assume a busca da liberdade, de desvencilhamento da esquerda, suas causas e tudo que ela representa. Nesse gesto de leitura, ser negro de direita é ser livre.

O sujeito se autodeclara antivitimista e contrário ao vitimismo, deixando entrever a censura que impede que circule dizeres sobre as dificuldades e sofrimentos vivenciados pelos negros ou menos favorecidos diante das desigualdades sociais, em FD de direita, esse tipo de proibição está na base do preconceito como forma de barrar outros sentidos.

Podemos ainda observar um deslizamento metafórico na palavra escravidão, que pode num outro gesto de leitura significar aprisionamento mental e ideológico, provocando um deslocamento de sentidos. Nessa nova perspectiva, a luta contra escravidão assume a busca da liberdade, de desvencilhamento da esquerda, suas causas e tudo que ela representa.

\section{Considerações finais}

Dado nosso gesto de análise pelo dispositivo teórico ao qual nos filiamos, podemos compreender como ocorre o processo de sobredeterminação ideológica do sujeito, cujo mecanismo, também, está sujeito a falhas. No caso em análise, observou-se a ocorrência de uma ruptura no processo de (des)identificação da posição do sujeito discursivo com o imaginário constituído, para a posição discursiva de presidente de uma instituição que visa promover política cultural igualitária e inclusiva para os negros. Nas materialidades analisadas, temos um sujeito-presidente que nega o racismo e se identifica como sendo de "direita", afetando, assim, o imaginário popular, para o qual a posição discursiva seria homogênea e determinada pela cor da pele. Os efeitos de sentido que o discurso dele provocou foi de desaprovação, de não representatividade, para aqueles que se inscrevem numa formação discursiva que assume a existência do racismo e, para enfrentá-lo, faz-se necessário implantação de política igualitária para os negros.

É importante ressaltar que o movimento de filiação a uma determinada formação discursiva pelo sujeito ocorre de forma inconsciente. Devido a isso, o sujeito do discurso é 
aquele que não sabe de onde vêm os seus sentidos, suas interpretações. Dizemos que o sujeito é interpelado ideologicamente, daí vem a tomada de posição, quando ele se identifica com determinados discursos e assume uma posição, mas esse processo está sujeito a falhas, rupturas ou enfraquecimento. Isso pode ter sido o fator que possibilitou o sujeito discursivo, sendo negro, identificar-se com posições discursivas que negam a escravidão e encaram o racismo como vitimíssimo, visto que o lugar social não é diretamente "colado" ao lugar discursivo.

Lembramos que esse estudo expressa nosso gesto de leitura, sabemos que outros podem ser possíveis, vez que os sentidos não se fecham.

\section{Referências}

DIAS, Cristiane. Textualidades seriadas: entre a repetição, a regularização e o deslocamento, o caso dos memes. Rasal - Revista de la Sociedad Argentina de Estudios Linguísticos, v. 2, p. 5574, 2019.

DIAS, Cristiane. Análise do discurso digital: Sujeito, espaço, memória e arquivo. Campinas, SP: Pontes Editores, 2018.

GRIGOLETTO, E. Do lugar social ao discursivo: o imbricamento de diferentes posições sujeito. In: Seminário de Estudos em Análise do Discurso UFRGS, 2005, Porto Alegre. Anais eletrônicos. Porto Alegre: UFRGS, 2005, p. 154-164. Disponível em: http://www.ufrgs.br/analisedodiscurso/anaisdosead/2SEAD/SIMPOSIOS/EvandraGrigoletto. pdf. Acesso em: dez. 2019.

INDURSKY, Freda. Unicidade, desdobramento, fragmentação: a trajetória da noção de sujeito em Análise do Discurso. In: MITTMANN, Solange; GRIGOLETTO, Evandra; CAZARIN, Ercília (Orgs.). Práticas Discursivas e identitárias. Sujeito \& Língua. Porto Alegre, Nova Prova, PPG-Letras/UFRGS, 2008. (Col. Ensaios, 22).

INDURSKY, Freda. Polêmica e denegação: dois fundamentos discursivos da denegação. Cadernos de estudos linguísticos. Campinas (19), juh/dez, 1990, p.117-122.

MARIANI, Bethania. As formas discursivas e a ameaça comunista. Revista Línguas e Instrumentos Linguísticos, Campinas, SP, n. 44, p. 270-289, jul./dez. 2019.

OLIVEIRA, C. Cavalcanti de. Das concepções e representações do gosto pela mídia: reflexões acerca da imagem estetizada da comida na divulgação de receitas culinárias. Culturas Midiáticas, v. 9, p. 136-150, 2016. 
OLIVEIRA, C. Cavalcanti de. A gourmetização como fenômeno mediático: uma análise dos processos de estetização do cotidiano por meio de práticas comunicacionais e de consumo com a gastronomia. 2018. 380 f. Tese (Doutorado em Comunicação e Linguagens) - Universidade Tuiuti do Paraná, Curitiba, 2018

ORLANDI, E. P. A contrapelo: incursão teórica na tecnologia - discurso eletrônico, escola, cidade. Revista Rua. Campinas, n. 16, Vol. 2, 2010.

ORLANDI, Eni P. Discurso em análise: Sujeito, Sentido e Ideologia. $3^{\mathrm{a}}$ ed. Campinas, SP: Pontes Editores, 2017.

PALMIERI JÚNIOR, Valter. A gourmetização em uma sociedade desigual: um estudo sobre a diferenciação no consumo de alimentos industrializados no Brasil. 2017. 1 recurso online (224 p.). Tese (doutorado) - Universidade Estadual de Campinas, Instituto de Economia, Campinas, SP. Disponível em: <http://www.repositorio.unicamp.br/handle/REPOSIP/325569>. Acesso em: 18 mai. 2020.

PÊCHEUX, M. Ler o arquivo hoje. In. ORLANDI, Eni P. (org) [et. al.]. Gestos de leitura: da história no discurso. Campinas: Editora da Unicamp, 2014, p.57-67.

PÊCHEUX [1975]. Semântica e Discurso: uma crítica à afirmação do óbvio / Michel Pêcheux; tradução: Eni Puccinelli Orlandi et al. $5^{\text {a }}$ ed. Campinas, SP: Editora da Unicamp, 2014a. POSSENTI, S.; OLIVEIRA, H. Violência e perversidade discursiva. Entreletras (Araguaína), v.12, n.01, 2021, p.06-24. 